Arent van Nieukerken*

\title{
Norwid, Heine, Gautier i początki modernizmu
}

http://dx.doi.org/10.12775/LC.2015.022

S t r e s z c z e n i e. Związki Norwida z symbolizmem i modernizmem, które były oczywiste dla Juliusza Gomulickiego, zostały ostatnio zakwestionowane. Zwłaszcza polscy norwidolodzy odeszli od uwydatniania podobieństw między poezją i prozą autora Vade-mecum a innowacjami literackimi jego francuskich współczesnych spod znaku wczesnego modernizmu. Polska norwidologia skupiała się (z nielicznymi wyjątkami) na zakorzenieniu jego twórczości w tradycji rodzimej. Niniejsza rozprawa porównuje motywy grobowe u Norwida (m.in. reprezentację agonii Chopina w Czarnych kwiatach) z podobnymi motywami w twórczości Théophile’a Gautiera (chodzi o jego wysoce poetycki opis tzw. grobu materacowego Heinricha Heinego). Nie dziwi, że opis Norwida pozwala ustalić związek z historią świętą, podczas gdy Gautier, który wyróżniał się doskonałym warsztatem poetyckim, używał obrazowania religijnego w celach ornamentalnych. „Metafizyczne” podejście Norwida do śmierci przypomina podobną praktykę u Baudelaire’a, który mieszał zdezaktualizowane obrazy sakralne z przedmiotami i sytuacjami niereligijnymi po to, by reprezentować metafizyczny obraz świata na opak, z nieobecnym Bogiem. Norwid jako poeta chrześcijański był w pewnym sensie bardziej staroświecki niż Baudelaire, lecz - z drugiej strony - jego literacka metoda mieszania sacrum i profanum była jeszcze bardziej śmiała niż sposób, w jaki francuski poeta odtwarzał ów konflikt między tradycją a nowoczesnością.

S l ow a kl u c z o w e : Cyprian Kamil Norwid; Heinrich Heine; Théophile Gautier; Charles Baudelaire; modernizm; symbol.

A b s t r a c t . Norwid, Heine, Gautier and the beginnings of modernism. Norwid's affiliations with symbolism and modernism that were obvious to Juliusz Gomulicki have been lately questioned. Instead of exposing the resemblances between his poetry and prose and the literary innovations of

* Autor wykłada literaturę polską i słowiańską na Uniwersytecie w Amsterdamie (UvA). Jest zagranicznym członkiem Polskiej Akademii Nauk, autorem książek Ironiczny konceptyzm. Nowoczesna polska poezja metafizyczna w kontekście anglosaskiego modernizmu (1998) i Perspektywiczność sacrum. Szkice o Norwidowskim romantyzmie (2007). Jest komparatystą. Zajmuje się przede wszystkim romantyzmem i modernizmem. E-mail: A.J.vanNieukerken@uva.nl. 
his French, early modernist contemporaries, Polish Norwid-specialists have (with a few exceptions) focused on his roots in the native Polish tradition. This paper compares funerary motives in Norwid's oeuvre (Black Flowers, Chopin's agony and death) with the treatment of similar motives in the oeuvre of Théophile Gautier (a highly poetical description of Heinrich Heine’s „Matratzengruft”). Not surprisingly, Norwid's description makes it possible to establish a link with sacred history, while Gautier - who was an excellent poetical craftsman - uses religious images and motives for "ornamental" purposes. Norwid's "metaphysical" approach to death is reminiscent of Charles Baudelaire's practice, who juxtaposed worn-out religious imagery with non-religious objects and situations in order to represent a metaphysical worldview à rebours in which God is not present but absent. As a Christian poet, Norwid was, in a certain sense, more anachronistic than Baudelaire, but on the other hand, his literary juxtapositions of sacred and profane motives are even more daring than the French poet's representations of this conflict between tradition and modernity.

Key words: Cyprian Kamil Norwid; Heinrich Heine; Théophile Gautier; Charles Baudelaire; modernism; symbol.

istorycy literatury często podkreślają wielką erudycję Cypriana Norwida. Jego lektury obejmowały wielką liczbę tekstów literackich i pozaliterackich pochodzących z różnych epok, począwszy od starożytności, a kończąc na najbardziej „awangardowej” poezji współczesnego mu Paryża. Stolica Francji była - zdaniem jej wieloletniego mieszkańca Adama Mickiewicza - tym miejscem, gdzie dochodzi do zbliżenia się między wszystkimi narodami europejskimi, które właśnie dzięki temu odkrywają - na obczyźnie - swą indywidualną rolę dziejową:

Jednym ze znamion naszej epoki jest owa dążność ludów do wzajemnego zbliżenia się, zetknięcia. Wiadomo, że Paryż jest ośrodkiem, sprężyną i narzędziem tych stosunków, że za pośrednictwem Paryża ludy europejskie uczą się poznawać nawzajem, a czasem nawet poznawać siebie same $^{1}$.

Największy znawca Norwida, Juliusz Gomulicki, uważał, że szczególne nowatorstwo dojrzałej poezji (i - dodaję od siebie - prozy) Norwidowskiej było właśnie skutkiem konfrontacji tradycji polskiego romantyzmu $\mathrm{z}$ najnowszymi prądami poetyckimi rozwijającymi się bujnie w Paryżu czasów Napoleona III. Zdaniem Gomulickiego najsłynniejszy tom

1 A. Mickiewicz, Dzieła, Warszawa 1955, t. 8, s. 15. 
poetycki Norwida, Vade-mecum, wprowadzając do poezji polskiej krajobraz miejski, był odpowiedzią na Baudelaire’owskie Kwiaty zła. Maciej Żurowski zaś zestawił poezję Norwida z parnasistowską twórczością Théophile’a Gautiera ${ }^{3}$. Jeszcze inni badacze (Piotr Śniedziewski ${ }^{4}$ ), idąc za (inną) sugestią romanisty Żurowskiego, analizowali twórczość Norwida w kontekście francuskiego symbolizmu. Zestawiali go z Mallarmém i Maeterlinckiem ${ }^{5}$. Problem w tym, że w tekstach Norwida nie ma żadnych biograficznych poszlak, by rzeczywiście znał on twórczość tych autorów i poetów, którzy przyczynili się do powstania kluczowej dla literatury XX wieku tradycji modernistycznej. Argumentem wspierającym tezę o (pre)modernizmie Norwida jest wprawdzie jego znajomość słynnej Podróży na wschód (Voyage en Orient) Gérarda de Nervala, którego później uznano za jednego z ojców-założycieli symbolizmu (por. PW, t. 11, s. 519). Czy jednak z tego wynika koniecznie, że Norwid znał poezję Nervala? Nie sposób odpowiedzieć na to pytanie. Jedynym dostępnym nam śladem (znalezionym już przez Gomulickiego) jest list wielbiciela Norwida Antoniego Zaleskiego do Kraszewskiego (z 23 grudnia 1858):

Trzeba tedy koniecznie, żebyśmy, S a m a r y t a n i e, zwrócili nareszcie uwagę czytającej publiczności na rzeczywiście zapoznanego Norwida, który - abstractione facta zbyt ciemnych albo zbyt śmiałych wyrażeń - jest zawsze znakomitym zjawiskiem na polu naszej literatury, i jeżeli Francja szczyci się swoim Nervalem, Ameryka - Edgarem Poe, Niemcy Hoffmannem i Jean Paulem, dlaczegóż nie możemy chwalić się naszym Norwidem, wyższym nawet od nich pod wielu względami. [PW, t. 8, s. 552]

Nie ulega natomiast wątpliwości, że Norwid prowadził twórczy dialog z polskimi i francuskimi romantykami. Korespondował (i spotykał się) z Zygmuntem Krasińskim i Augustem Cieszkowskim. Bez większego wysiłku można odnaleźć ślady ich koncepcji historiozoficznych (wyłożonych w takich mało „modernistycznych” dziełach jak Przedświt i Ojcze-Nasz) w jego poezji, tyle że w formie zupełnie przemienionej, w niczym już nieprzypominającej pierwowzorów. Nie sposób też przeoczyć obecności (jednak raczej w prozie eseistycznej i listach Norwida) najsłynniejszych poetów zachodnioeuropejskich tej epoki. Rolf Fieguth analizował twórczość Cypriana Norwida w kontekście Victora Hugo i Charles’a Baudelaire’a, porównując m.in. sposoby budowania cyklu poetyckiego u Norwida i Baudelaire'a ${ }^{6}$.

W porównaniu z literaturą francuską i angielską obecność literatury niemieckiej jest u Norwida raczej znikoma. Odwołania do niej nie mają większego znaczenia dla poetyki Norwidowskiej. W jego listach można jednak znaleźć bardzo ciekawą charakterystykę twórczości Niemca zamieszkałego w Paryżu, Heinricha Heinego:

2 Por. M. Żurowski, Norwid i Gautier, [w:] idem, Między renesansem a awangardq̨: o literaturze europejskiej z perspektywy komparatysty, Warszawa 2007.

3 Por. C. Norwid, Pisma wszystkie, Warszawa 1971, t. 11, s. 83, 91 (opracowany przez J. W. Gomulickiego kalendarz biograficzny). Kolejne odwołania do tego wydania będą oznaczane skrótem PW z podaniem numerów tomu i stronicy.

${ }_{4}$ Zob. P. Śniedziewski, Mallarmé - Norwid: milczenie i poetycki modernizm we Francji oraz w Polsce, Poznań 2008.

5 Por. M. Żurowski, Hopkins, Mallarmé i Norwid?, [w:] idem, Między renesansem a awangardq.

6 Zob. R. Fieguth, Gombrowicz z niemiecka gęba i inne studia komparatystyczne, Poznań 2011, (rozdz.: „Vade-mecum Cypriana Norwida w kontekście Wiktora Hugo i Charles'a Baudelaire'a"). 
I tak np. któż nie zna H e i n e g o ? Otóż - proszę wziąść trzecią część Spinozy, 11/4 Joba, 1/4 Hafiza, $1 / 2$ Byrona, $1 / 2$ niemieckiego studenta, a wypadnie całość, która da coś tak równego Heinemu, że jeśli to nie on będzie, to sprzeciwi się temu ta tylko cząsteczka mała, któ ra nim jest i powinna była być. Takie studium niech krytyk zrobi z krytyką dzisiejszą, a dopiero wierzyć będę, że wie, co mówi i o c e n i a - ale coż się wtedy pokaże?... To już jeden sposób poszukiwania krytycznej prawdy. [PW, t. 8, s. 281]

Owa bardzo komparatystyczna charakterystyka (będąca wręcz zaproszeniem do badań porównawczych) pochodzi z listu do Marii Trębickiej (Paryż, sierpień 1856)7 , adresatki, na której opinii Norwidowi zależało, m.in. dlatego, że kiedyś była przyjaciółką Marii Kalergis.

Pewnej pikanterii dodaje sprawie fakt, że w tym samym liście, w którym mowa o Heinem, Norwid na prośbę adresatki wypowiada się o twórczości Lucjana Faleńskiego („a uto r a Termopil”), za którego Maria Trębicka trochę później wyszła za mąż, przedkładając go nad Norwida. Otóż to właśnie „autorowi Termopil” daje Norwid konkretne rady, przy czym ten fragment listu bezpośrednio poprzedza charakterystykę twórczości Heinego:

Niech się stara autor o znajomość bezpośrednią motywów dzisiejszej literatury pięknej i przyjdzie do takiej ich znajomości, by mógł nieledwie kreskami obliczyć, c o i z c ze go żyje? A potem niech weźnie żywota ile można najprywatniejsze onych autorów i przepatrzy je z bliska. To mu da moc, której potrzeba tyle, aby te krzywości krytyki takiej poprostować i narysować inaczej. [PW, t. 8, s. 281]

Dzieło literackie powinno więc wyrażać egzystencjalną prawdę „biograficznego” autora. W wypadku poezji Heinego postulat ten został jednak tylko częściowo spełniony (Norwid wspomina nawet o „cząsteczce małej”). Czy jednak wina leży tu tylko po stronie Heinego? Czy owa wtórność poezji epoki, w której najważniejsze były sprawy potoczne, codzienne oraz różnego rodzaju „interesy” dotyczące „realnego położenia” człowieka („wiek jest kupiecki i przemysłowy” [PW, t. VIII, s. 433, List do Magdaleny Łuszczewskiej, 1860]), nie jest rezultatem pewnych nieodwracalnych przemian społecznych? Wszelkie próby buntu przeciw takiemu stanowi rzeczy są w tej sytuacji skazane na niepowodzenie. Powodują tylko porażkę osobistą, jak w przypadku samego Norwida. Kiedyś rzeczywistość otaczająca i w pewnym sensie kształtująca człowieka była jednak zupełnie inna. Możemy wciąż jeszcze obcować z tą przeszłą rzeczywistością, czytając dzieła arcymistrzów ducha.

Po charakterystyce poezji Heinego Norwid, udzielając - za pośrednictwem Marii Trębickiej - kolejnej rady Lucjanowi Faleńskiemu, pisze:

\footnotetext{
7 W tym samym liście znajdujemy francuskojęzyczny cytat z Goethego: „nous parlons trop, nous devrions moins parler et plus dessiner". Cytat ten pochodzi z obszernego wstępu Henriego Blaze'a do jego przekładu Fausta (cz. 1 i 2) na francuski (Le Faust de Goethe. Traduction revue et complète, précédée d'un essai sur Goethe par m. Henri Blaze, Paris 1847, s. 59). W jednym z pochodzących z lat siedemdziesiątych XIX wieku wykładów o Juliuszu Słowackim Norwid przytacza natomiast linijkę z pierwszej części Fausta po niemiecku. Cytat ten, albo raczej reminiscencja, został już przed laty zlokalizowany przez Gomulickiego: „Was kannst du mir, der arme Teufel, geben?” (powinno być: „Was willst du, armer Teufel, geben”. We francuskim przekładzie prozą pióra Blaze'a wers ten brzmi: "Que veux tu me donner, pauvre diable?" [ibidem, s. 126]). Dbałość Norwida o jambiczny tok wersu - a więc taki jak w oryginale, sugeruje, że próbował on czytać Goethego po niemiecku, może zestawiając oryginał z francuskim czy nawet polskim przekładem.
} 


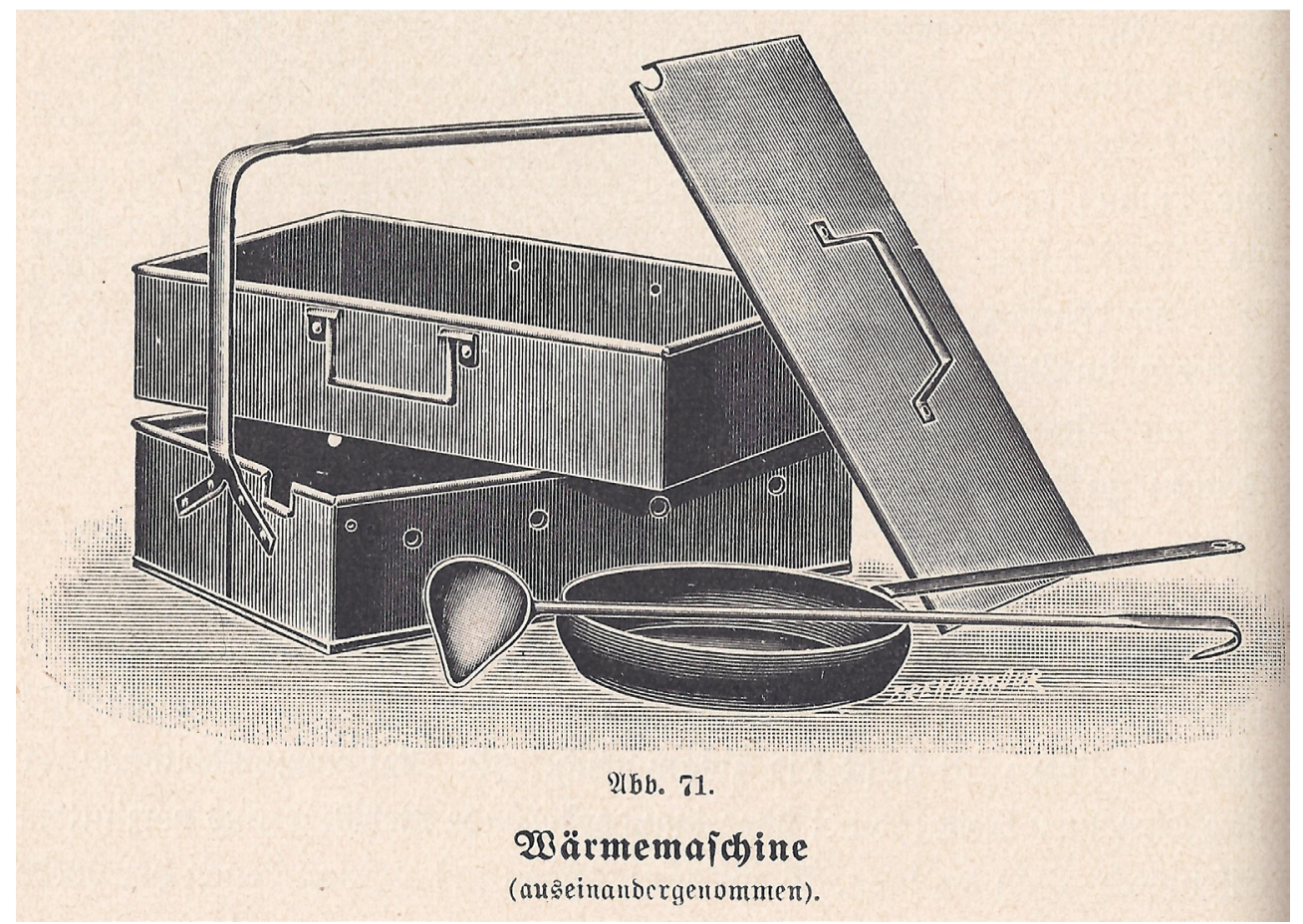

Teraz, co do głębszego poglądu na kierunki duchowe, inaczej radzę studiować. I tak: proszę zamknąć się i wziąść sobie Homera, Danta, Shakespeare’a etc. i Ewangelię św. Łukasza. I proszę czytać sobie swobodnie cokolwiek aż do zaczytania się - i niech kto zakołata z interesem jakim potocznym... od którego z tych autorów, przeniósłszy oczy z książki w realne położenie, będzie się czytelnik czuł najprzytomniej na swoim miejscu, gotów do traktowania interesu? ... To znów jest studium do pojmowania i ważenia wartości wyższego rzędu. Ale to tylko dwa wzory pracowania - jest ich tyle! - bo któż to umie plynnie czytać? - to tak trudno. [PW, t. 8, s. 281-282]

Czy z tych rad przeznaczonych dla „autora Termopil” wynika coś dla oceny poezji współczesnej Norwidowi? Wydaje się, że nie można już pisać tak, jak pisali niegdyś giganci ducha (Homer, Dante, Shakespeare). Utwory napisane na ich modłę nie odpowiadałyby bowiem „żywotowi najprywatniejszemu” poety żyjącego w epoce „interesów potocznych”. Przydatna okazałaby się co najwyżej Ewangelia wg św. Łukasza, która jednak nie jest w pierwszym rzędzie tekstem literackim. Wydaje się, że w tych rozważaniach Norwid wychodzi od koncepcji literatury opierającej się na - wprawdzie specyficznie rozumianej - zasadzie mimesis. Poezja powinna oddawać „ducha” wieku, który wycisnął swoje piętno na jednostkach. Współczesna Norwidowi poezja (zwłaszcza liryczna) w pewnym sensie aż za dobrze wywiązuje się z tego zadania. Wyraża bowiem sytuację człowieka, który właśnie jako poeta jest wyobcowany z rzeczywistości dziejowej. Innymi słowy: nie interesuje 
się swoim „realnym położeniem” w anonimowym społeczeństwie przemysłowym. Norwid myślał tu przede wszystkim o lirycznym emocjonalizmie poetów drugiego pokolenia polskiego romantyzmu, traktując poezję swojego młodszego kolegi Teofila Lenartowicza jako swoiste pars pro toto ${ }^{8}$. Poezja ta nie uobecniała jednak autentycznego stanu duszy nowoczesnego poety lirycznego, zawieszonego między rzeczywistością „cywilizacji komercyjnej i technicznej”" a mniej lub bardziej autonomicznym światem poezji. Oddawała bowiem tylko jedną stronę nowoczesnego podmiotu, a mianowicie tę, która wydaje się najdalsza od potocznej rzeczywistości.

Zadanie autentycznego poety „wieku kupieckiego i przemysłowego” polegałoby więc nie tylko na tym, by poprzez poezję docierać do pewnej głębszej, np. bardziej źródłowej warstwy egzystencjalnej (na ogół związanej z sacrum i z kategorią tajemnicy). Nie chodzi również o konstruowanie przestrzeni sztuki oczyszczonej z migotliwości przemijających zjawisk. Kamieniem probierczym spełnienia Norwidowskiego postulatu autentyczności jest umieszczenie poezji, mającej być reprezentacją „życia najprywatniejszego”, w kontekście rzeczywistości „codziennej”. W danym wypadku oznacza to uobecnienie w obrębie tekstu rozdarcia podmiotu typowego dla statusu egzystencjalnego człowieka w epoce „przemysłu i kupiectwa”. Ów postulat miał doniosłe konsekwencje dla poromantycznej twórczości religijnej (i w ogóle „metafizycznej”). W tej epoce sacrum nie znajdowało już przecież w sposób naturalny odbicia w sferze życia codziennego. Obrzędy stały się martwe. Nie należało jednak z tego wyciągnąć wniosku, że tajemnica została bezpowrotnie wyrugowana ze sfery powszedniości. Uległa raczej przemieszczeniu. Trzeba było więc pogłębić samą ideę powszedniości, skonstruować ją tak, by ukazała się ona sama w sobie jako niejednoznaczna, pęknięta ${ }^{10}$ i otoczona aurą tajemniczości. Taki akt konstrukcyjny nie jest jednak czynem anonimowego budowniczego wycofującego się z przestrzeni dzieła sztuki (jak np. w poezji Mallarmégo), lecz wiąże się explicite $\mathrm{z}$ autobiografią poety. Więcej: odtwarzanie owej autobiografii nie jest prostym aktem opisującym, lecz częścią procesu jej przeobrażenia poprzez wprowadzenie konkretnie pojętej perspektywy sakralnej (chodzi tu o historię świętą zrelacjonowaną w Ewangelii), dzięki której protagonista (autor) staje się nowym człowiekiem. Owa intuicja, że ta sama przestrzeń może się człowiekowi ukazywać pod dwiema - wprawdzie nierównoprawnymi - postaciami, jako przestrzeń powszedniości i jako przestrzeń sakralna, jest wyrazem przekonania o ironicznej istocie egzystencji nowoczesnego człowieka.

\section{2.}

Cały ten wywód o naturze ironii pochodzi z serii listów do Marii Trębickiej, gdzie mowa również - jak widzieliśmy - o Heinrichu Heinem, który z punktu widzenia współczesnej

\footnotetext{
${ }^{8}$ W tym samym liście do Marii Trębickiej Norwid ocenia jednak pozytywnie balladę Lenartowicza Złoty kubek ze względu na równowagę między "uczuciem" a "myślą głęboką" [PW, t. 8, s. 281].

9 Por. H. Friedrich, Die Struktur der modernen Lyrik, Hamburg 1956, s. 25.

10 Pod tym względem istnieje pewne podobieństwo między twórczą praktyką Norwida a poezją modernistyczną. Por. następującą obserwację Hugona Friedricha: „Insbesondere zeigt er sich in einem Verfahren, das aus der realen Welt Bruchstücke entnimmt, sie in sich selbst wohl sorgfältig durcharbeitet, aber doch darauf achtet, daß ihre Bruchflächen nicht aufeinander passen. In solchen Dichtungen erscheint die reale Welt durchzogen von einem wirren Geäder schwerer Risse - und ist nicht mehr real" (H. Friedrich, op. cit., s. 145). Różnica polega na tym, że Norwidowska transcendencja nie jest pusta.
} 
mu krytyki literackiej był ironistą par excellence. Dlaczego więc Norwid w swojej charakterystyce twórczości niemiecko-żydowskiego poety unikał pojęcia ironii? Czy poezja Heinego była z punktu widzenia Norwida niedostatecznie ironiczna, czy może ironiczna w niewłaściwym tego pojęcia znaczeniu? Współcześni Heinego zarzucali mu często złośliwy stosunek do bliźnich (zwłaszcza do kolegów-literatów), który miał się wyrażać $\mathrm{w}$ instrumentalizowanej ironii. Nie ulega wątpliwości, że nieraz poeta posługiwał się tą bronią. Ironia jako oręż destrukcyjny ma jednak niewiele wspólnego z ironią romantyczną w rozumieniu Friedricha Schlegla, według której twórcze akty artysty (poety) polegają na „nieustannej przemianie autokreacji i autodestrukcji”, łączącej naiwność z artystyczną premedytacją ${ }^{11}$. Tak rozumiana ironia romantyczna wyciąga konsekwencje z Kantowskiego postulatu niepoznawalności bytu samego w sobie, oderwanego od podmiotu poznającego, i przenosi podmiotowy charakter aktów poznawczych na teren sztuki i poezji. Rzeczywistość okazuje się tu treścią relacji między podmiotem a przedmiotem, przy czym podmiotowi przypada rola czynna. Rzeczywistość jest w pewnym sensie przez niego stwarzana, konstruowana. W przypadku artysty (poety) romantycznego ów z konieczności twórczy stosunek podmiotu do rzeczywistości staje się przedmiotem rozważań autotematycznych. Okazuje się przy tym, że rzeczywistość jest nieskończona. Sfera „rzeczy samej w sobie” jest bowiem z istoty niepoznawalna, mimo że właśnie ona warunkuje rzeczywistość „zjawiskową”. Wskutek niepoznawalności dziedziny „rzeczy samej w sobie” człowiek nie może mieć jakiegoś ostatecznego wyobrażenia o rzeczywistości „zjawiskowej”. Jest ona nieskończona w tym sensie, że przybiera dlań coraz to nowe kształty. Owe nowe kształty nie jawią się podmiotowi samorzutnie, lecz są samą materią (a nie tylko treścią) jego aktów twórczych. Owe akty twórcze są także aktami, za których pośrednictwem stwarza on siebie samego. Żaden akt (samo)tworzenia nie odpowiada jednak nieskończonej istocie ludzkiej egzystencji. Nieadekwatność pewnego aktu twórczego i potrzeba zastąpienia jego treści treścią kolejnego aktu twórczego wiąże się z koniecznością negacji pierwszego aktu na rzecz drugiego i tak ad infinitum. Wydaje się więc, że owe akty nie sumują się. Nie dochodzi do wyższej (Heglowskiej) syntezy.

Różnica między tak rozumianą ironią romantyczną, która również nie była obca poezji Heinego (nie wolno jego typu ironii ograniczyć do funkcji czysto polemicznych), a ironią Norwidowską polega na tym, że w twórczości Norwida konkretne elementy jakiejś danej sytuacji „rzeczywistej”, powodujące ironiczny „zgrzyt” lub „pęknięcie”, nie są wynikiem dwóch aktów twórczych, z których pierwszy zostaje zanegowany przez drugi. W Norwidowskiej ironii elementy rzeczywistości są bowiem dane a priori. Podmiot (,ja”) dostrzega i opisuje je „obiektywnie”, w pewnym sensie nawet „naiwnie”. Dopiero konstatacja zawartego w tej sytuacji „zgrzytu”, „pęknięcia”, jawi się jako akt twórczy podmiotu sensu stricto (albo raczej jako jego własny wkład do sytuacji, którą odtąd postrzega jako ironiczną). Sama sytuacja nie powstaje więc wskutek twórczości podmiotu, nie jest przez niego konstruowana, lecz z d a r z a mu się (konstruktem jest dopiero jej zapis, tekst, ale jako wierne odzwierciedlenie rzeczywistości - „powierzchni” bytu). Stwierdzenie ironicznego statusu ludzkiego bytowania nie może przy tym być aktem jednego podmiotu dokonanym w odosobnieniu od wszystkich innych podmiotów. Zakłada obecność słuchacza (lub współobserwatora), który wyciąga z opisanej sytuacji ten sam wniosek co „ja” (podmiot mówiący), przy czym

11 Por. F. Schlegel, Werke in zwei Bänden, Berlin-Weimar 1980, t. 1, s. 195 (Fragment 51). 
ów wniosek nigdy nie zostaje sformułowany explicite (stąd też istnieje możliwość zapoznania ironicznej istoty sytuacji; przyczynia się ona do częstych w twórczości Norwida przykładem jego korespondencja z Marią Trębicką - zakłóceń komunikacyjnych).

Zdarzeniowość i dialogiczność są głównymi wyznacznikami niemal wszystkich tekstów artystycznych Norwida. Jego epistolografia jawi się w tym kontekście jako w pewnym sensie uprzywilejowany gatunek artystyczny, bo relacja między nadawcą a adresatem przekazu jest w niej jawnym czynnikiem gatunkowym. Jednym z istotnych zadań poety (artysty) okazuje się więc wydobywanie, o b j a w i a n i e, ironicznej natury ludzkiego bytowania na tym świecie wobec nieskończoności Bożej transcendencji, w której człowiek uczestniczy dzięki podwójnej naturze Boga-człowieka, Chrystusa. Tak rozumiana ironia egzystencjalna nie jest aktem intelektualnym, uobecniającym kilka na pierwszy rzut oka sprzecznych „myśli”, które godzi ze sobą podmiot uświadamiający sobie kontrast między swą życiową ograniczonością a nieskończonością twórczej wyobraźni, lecz aktem „performatywnym”, wcielającym myśl poprzez przeobrażenie autobiografii samego poety.

Przyjrzyjmy się w tym kontekście fragmentowi francuskojęzycznego listu Heinego do Alexandre’a Dumasa (ojca) i porównajmy go z zakończeniem słynnego opisu wizyty, którą Norwid złożył wtedy ciężko już choremu Chopinowi, z Czarnych kwiatów. Oba fragmenty zostały skonstruowane wokół motywu śmiertelności człowieka i konieczności „przenosin”, tzn. „przeprowadzki”, albo raczej „wyniesienia się” na tamten świat. Chodzi w nich więc o rzeczy ostateczne:

Il y a quelques semaines que vous exprimez dans votre feuille l'intention de venir bientôt me voir. C'était une bonne pensée. Mais je vous préviens que, si vous remettez votre visite encore longtemps, il se pourra bien que vous ne me trouviez plus dans mon appartement actuel, rue d'Amsterdam, 50, et que je sois déjà parti pour une autre demeure, qui m'est tout à fait inconnue, de sorte que je ne pourrai laisser à mon portier ma nouvelle adresse pour le cas où des amis retardataires comme vous viendraient demander après moi. Je ne fais pas une grande idée de ma future résidence ; je sais seulement qu'on y entre par un couloir obscur et fétide, et cette entrée me déplait d'avance ; aussi ma femme pleure quand je parle de ce déménagement ${ }^{12}$.

[Kilka tygodni temu wyraził Pan w swoim liście zamiar odwiedzenia mnie wkrótce. Był to dobry pomysł. Ale uprzedzam Pana, iż mogłoby się zdarzyć, jeżeli Pan będzie jeszcze długo zwlekał z tą wizytą, że nie zastanie Pan mnie już w moim obecnym mieszkaniu przy rue d’Amsterdam 50. Może wyruszę już wtedy do innego miejsca zamieszkania, które jest mi całkowicie nieznane, tak że nie będę mógł zostawić u portiera nowego adresu dla opieszałych przyjaciół takich jak Pan, którzy będą pytać o mnie. Nie zastanawiam się specjalnie nad nowym miejscem pobytu. Wiem tylko tyle, że wchodzi się tam przez ciemny i cuchnący korytarz, a denerwuje mnie to z góry; moja żona placze, kiedy wspominam o tej przeprowadzce.]

Nowe pomieszczenie, do którego Heine się „przeprowadzi” i w którym jego przyjaciele nie będą mogli go odwiedzać, to oczywiście grób.

Norwid opiera swój opis wizyty u Chopina na tej samej dwuznaczności semantycznej:

Owóż - przerywanym głosem, dla kaszlu i dawienia, wyrzucać mi począł, że tak dawno go nie widziałem - potem żartował coś i prześladować mię chciał najniewinniej o mistyczne kierunki,

12 H. Heine, Briefe, red. G. Erler, Leipzig 1969, s. 405-406. 
co, że mu przyjemność robiło, dozwalałem - potem z siostrą jego mówiłem - potem były przerwy kaszlu, potem moment nadszedł, że należało go spokojnym zostawić, więc żegnałem go, a on, ścisnąwszy mię za rękę, odrzucił sobie włosy z czoła i rzekł: „.. .Wy n o s z ę s i ę ! ...” i począł kasłać, co ja, jako mówil, usłyszawszy, a wiedząc, iż nerwom jego dobrze się robiło silnie coś czasem przecząc, użyłem onego sztucznego tonu i całując go w ramię rzekłem, jak się mówi do osoby silnej i męstwo mającej: „...Wynosisz się tak co rok... a przecież, chwała Bogu, oglądamy cię przy życiu”.

A Chopin na to, kończąc przerwane mu kaszlem słowa, rzekł: „Mó wi ę ci, że wy noszę się z mieszkania tego na plac Vendôme..."

To była moja ostatnia z nim rozmowa, wkrótce bowiem przeniósł się na plac Vendôme i tam umarł, ale już go więcej po onej wizycie na ulicy Chaillot nie widziałem... [PW, t. 6, s. 179]

Charakter pomieszczenia, do którego Heine wkrótce miał się przeprowadzić, adresat listu mógł łatwo odgadnąć na podstawie opisu prowadzącego do niego wejścia. Jest to ciemny korytarz, w którym pachnie zgnilizną. Śmierć, albo raczej to, co znajduje się po drugiej stronie korytarza, jako takie pozostaje wielką niewiadomą. W Czarnych kwiatach natomiast tajemnica śmierci zostaje do pewnego stopnia wyjaśniona. Jawi się ona jako p r ze prow a d z k a w chrześcijańskim sensie, a nie jako kres, jak wydaje się sugerować Heine, który wypowiada się konkretnie tylko o pośmiertnych losach swojego ciała, podczas gdy przyszłość jego duszy pozostaje nieprzeniknioną zagadką. U Norwida, w odróżnieniu od Heinego, niebo i ziemia wzajemnie się przenikają, przy czym głębsze znaczenie wyrazu „wynoszenie się” (albo przenoszenie się: „wkrótce bowiem przeniósł się na plac Vendôme i tam umarl”) jest rezultatem podwójnej sytuacji dialogicznej. Pierwszy dialog, konkretna i brzemienna w nieporozumienia rozmowa, odbywa się na poziomie świata przedstawionego między narratorem wewnątrztekstowym a jego interlokutorem Chopinem. Drugi dialog toczy się zaś na wyższym poziomie tekstu, między autorem a odbiorcą „wirtualnym”, kiedy rozszyfrowują oni wspólnie ukryty sens owych przenosin (z tego sensu Chopin, wypowiadając się żartobliwie, zgodnie z konwenansami rozmowy towarzyskiej, o „kierunkach mistycznych", w aktualnej chwili rozmowy nie zdawał sobie sprawy). Wydobycie chrześcijańskiego sensu nieporozumienia wynikającego z semantycznej dwuznaczności pewnego zwrotu przeobraża przy tym także sam podmiot mówiący, uobecniając bożo-ludzką istotę najdrobniejszych, „najprywatniejszych” zdarzeń z ludzkiego życia.

\section{3.}

W tym miejscu trzeba zadać pytanie, czy taka sakralizująca lektura sytuacji codziennej jest w ogóle dopuszczalna? Czy w samym tekście są jakieś sygnały, które usprawiedliwiają taką interpretację? Czy nie jest ona nadużyciem? Wydaje mi się, że model lektury jako aktu pozyskiwania sacrum z powierzchni życia codziennego został explicite wpisany w strukturę Czarnych kwiatów jako tekstu. Na początku tych pozornie luźnych kartek pamiętnikarskich narrator wspomina, że w czasie swojego pobytu w Rzymie często odwiedzał katakumby. Pewnego razu, kiedy stamtąd wracał, poruszyły go małe „ampułki”, które w przeszłości prawdopodobnie zawierały krew męczenników. Owe „ampułki” oddają istotę życia i śmierci starożytnego chrześcijanina (przy czym okoliczność, że zostały rozbite, nabiera szczegól- 
nego znaczenia). Właśnie w tym kontekście powinniśmy interpretować następujące po tym wspomnieniu „nowoczesne” opisy życia i śmierci znajomych Norwida (Stefana Witwickiego, Chopina, Słowackiego, Mickiewicza):

... To - pamiętam, jednego razu w Rzymie z katakomb powracałem [...] - ale tyle tylko oto wspomnę, iż to ogromne podziemne miasto z napisami i rysunkami swymi okazało mi, jako przez całe akta dramatu tego seraficznie-krwawego nie była prawie jedna kropelka krwi wylana bez uszanowania jej i omodlenia braterskiego współwyznawców. Te szkła, dziś błękitno-krzemiennej barwy, które jako ampułki rozbite (albo i całe) w katakombowych sarkofagach, do półek biblioteki podobnych, tu i ówdzie leżą, błogie robią wrażenie, świadcząc, jak zbierano rozpryśniętą po ścianach katowni i schodach gmachów publicznych krew męczeńską. Tak ją szafowano szeroko i wspaniale, jako owczarni krew bogaty pan szafować może - a tak skąpi jej byli!! [PW, t. 6, s. 176]

W opisie umierającego Chopina na powierzchni świata przedstawionego brak atrybutów wskazujących w sposób jednoznaczny na transcendencję. Wydaje się jednak, że $\mathrm{z}$ innego punktu widzenia ten opis jest właśnie nowoczesnym odpowiednikiem rozbitych („albo i całych”) ampułek, które w rzymskich katakumbach przechowały krew męczenników. Relację między obrazem ampulek, stanowiących „bibliotekę”, a opisem umierających znajomych można by ująć jako przykład tekstowej kategorii autoreferencjalności. Wtedy jednak mielibyśmy do czynienia z artefaktami „autotelicznymi”, co kłóciłoby się z postulatem Norwida, że poezja (i w ogóle sztuka) powinna być objawieniem „najprywatniejszych żywotów" konkretnych osób. Właśnie pod tym względem poezja i proza Norwida różni się istotnie od twórczości prawie wszystkich jego starszych i młodszych współczesnych, zarówno Polaków, jak i Francuzów, romantyków i (wczesnych) modernistów.

Można to jeszcze dobitniej unaocznić na przykładzie innego tekstu związanego z życiem, albo raczej śmiercią, Heinego. Jedyna znana nam wzmianka o nim w twórczości Norwida - cytowałem ją już na początku tego tekstu - pochodzi z listu do Marii Trębickiej z sierpnia 1856. Heine umarł zaś w lutym tego samego roku. Po jego zgonie ukazały się liczne nekrologi w prasie niemieckiej i francuskiej, m.in. w czytywanym przez Norwida „Journal des Débats”. Palma pierwszeństwa należała się jednak nekrologowi napisanemu przez francuskiego poetę Théophile’a Gautiera i opublikowanemu w „Moniteur Universel” (również ta gazeta była dobrze znana Norwidowi ${ }^{13}$ ). W kilka miesięcy później Gautier przedrukował ten nekrolog we wstępie do jednego z tomów wydania Dzieł zebranych Heinego po francusku - był to tom Tableaux des Voyages (francuski przekład słynnych Reisebilder) ${ }^{14}$. Aura napisanego niemal już impresjonistyczną prozą tekstu Gautiera przypomina trochę atmosferę Czarnych kwiatów. Istotniejsze są jednak różnice.

Uderzającą zbieżnością między opisami wizyt u Chopina i Heinego jest np. kontrast między tragicznym stanem ich zdrowia a nieco frywolnym, wręcz żartobliwym sposobem, w jaki prowadzą konwersację z osobami ich odwiedzającymi. Witając się z Gautierem, Heine narzekał na winietę poprzedzającą obszerny szkic o jego twórczości pióra tłumacza literatury niemieckiej i krytyka Saint-René Taillandiera w „Revue des Deux Mondes”. Został

13 Por. Z. Trojanowicz, E. Lijewska, Kalendarz życia i twórczości Cypriana Norwida, Poznań 2007, t. 2, s. 33.

14 Th. Gautier, Henri Heine, [w:] Reisebilder. Tableaux de voyage par Henri Heine précedée d'une étude sur H. Heine par Théophile Gautier, Paris 1856 (zob. http://gallica.bnf.fr/ark:/12148/bpt6k2064110/). 
na nim przedstawiony jako „wychudły i pochylający głowę Chrystus”, trochę podobny do obrazu pędzla XVI-wiecznego malarza hiszpańskiego Moralesa ${ }^{15}$. Sam Heine wolałby, aby jego podobizny były piękne jak ładne kobiety. Chciał wyglądać na nich tak jak wtedy, kiedy był „młody i kwitnący”. „Uduchowionymi ironiami”" ${ }^{16}$ odznaczają się również fragmenty z listów samego Heinego, kiedy wspomina on o swoich nieznośnych bólach w „materacowym grobowcu" (Matratzengruft).

W nekrologu pióra Gautiera znajdujemy sporo elementów na pierwszy rzut oka związanych z s a c r u m, chociaż poeta ten, który sławę zawdzięczył swojemu już bardzo parnasistowskiemu zbiorowi Émaux et camées, bynajmniej - w odróżnieniu od Norwida - nie pretendował do bycia twórcą chrześcijańskim. Matratzengruft, w którym Heine spędził ostatnie lata swojego życia, kojarzy się jego francuskiemu przyjacielowi z nową Golgotą:

Le poète me tendit avec effort une petite main douce, fluette, mate et blanche comme une hostie $[\ldots] .[\ldots]$

À quelques mois de là, Henri Heine prit le lit pour ne plus le quitter : il resta huit ans cloué sur la croix de la paralysie par les clous de la souffrance. Pendant cette longue agonie il offrit le phénomène de l'âme vivant sans corps, de l'esprit se passant de la matière, la maladie l'avait atténué, émacié, disséqué comme à plaisir, et dans la statue du dieu grec taillant avec la patience minutieuse d'un artiste du moyen âge un Christ décharné jusqu'au squelette, où les nerfs, les tendons, les veines apparaissent en saillie. Ainsi dépouillé, il était beau encore. [...] Lazare sortait de son caveau pendant quelques minutes : ce spectre, qui semblait dans son linceul une effigie funèbre couchée sur un monument, trouvait une voix pour causer, pour rire, pour lancer de spirituelles ironies, pour dicter des pages charmantes, pour donner l'essor à des strophes ailées, et, aux jours où la pierre de sa tombe lui meurtrissait plus durement les reins, pour gémir des lamentations aussi tristes que celles de Job sur son fumier ${ }^{17}$.

[Poeta z wysiłkiem podał mi swoją drobną dłoń, miękką, wątłą, matową i biała jak hostia [...].[...]

W kilka miesięcy później Heine położył się do łóżka i już nigdy z niego nie wstał. Spędził w nim osiem lat, gwoździami cierpienia przybity do krzyża bezwładu. W czasie tej długiej agonii był podobny do duszy żyjącej bez ciała, do ducha obywającego się bez materii; choroba wycieńczyła go, jakby przeprowadziła na nim sekcję, i z cierpliwą starannością artysty średniowiecznego wyciosała z tego posagu greckiego boga - Chrystusa wychudlego na podobieństwo kościotrupa, na którym uwydatniły się ścięgna i żyły. Tak ogołocony byt wciąz piękny. [...] Łazarz wyszedt na kilka minut ze swojego grobu w pieczarze: owo widmo, które w swoim całunie wydawało się portretem żałobnym spoczywającym na nagrobku, wydobyło z siebie głos, by rozmawiać, śmiać się, puszczać w ruch uduchowioną ironię, dyktować urocze stronice, wzbijać się wzwyż uskrzydlonymi zwrotkami, i, w dniach kiedy kamień grobowy ostro gniótł jego lędźwie, zawodzić skargi nie mniej smutne niż lamenty Hioba na gnojowisku.]

Drobiazgowy i wysoce zmetaforyzowany opis cierpiącego w swoim materacowym grobowcu Heinego z nekrologu Gautiera nie jest raczej spełnieniem prośby poety, by gość

15 Ibidem, s. II.

16 Ibidem, s. VII.

17 Ibidem, s. VI-VII (kursywa moja - A.v.N.); „être comme Job sur son fumier" - „być nędznym jak Łazarz". Przypomnijmy w tym miejscu, że na literacki wizerunek Heinego zarysowany przez Norwida w liście do Marii Trębickiej miało się też złożyć „1/4 Joba”. 
„przedstawił go pięknego jak ładne kobiety”. Nie sposób jednak zaprzeczyć, że opis ten wywołuje u czytelnika wrażenie estetyzacji. Wydaje się przy tym całkowitym zaprzeczeniem opisu umierającego Chopina z Czarnych kwiatów, w którym prawie nie ma atrybutów o bezpośredniej wymowie sakralnej. U Gautiera brak (jak powiedziałby Norwid) czynnika „parabolicznego”. Występujące w szczególnym zagęszczeniu motywy sakralne („drobna i miękka dłoń [...] biała jak hostia”; „przybity gwoździami cierpienia do krzyża paraliżu”) nie odsyłają tu do historii świętej, do dziejów cierpienia i zmartwychwstania Chrystusa. Spełniają bowiem zupełnie inną funkcję. Uwznioślają obraz umierającego człowieka, przy czym owa wzniosłość odbiera śmierci jej unicestwiającą moc. U czytelnika powstaje nastrój melancholijnej kontemplacji (okazuje się, że nawet najgenialniejszy człowiek jest skazany na cierpienia) połączony z podziwem dla umiejętności stylistycznych autora nekrologu. Jeżeli już Gautier chce być „kapłanem”, to takim, który sprawuje kult piękna (l’art pour l'art). Piękno zaś stanowi tu swoje własne usprawiedliwienie. Nie potrzebuje wsparcia ze strony etyki (Dobra) ani religii. I to właśnie owo autonomiczne piękno wizerunku konającego artysty Gautier przeciwstawia „realnemu położeniu” (por. wspomniany wyżej list Norwida do Marii Trębickiej) codziennego umierania (stanowiącego np. temat Norwidowskiego wiersza Nerwy). Nieskazitelne rzemiosło artystyczne francuskiego poety wyjmuje arcyludzkie cierpienie Heinego z zasadniczo nieczystej sfery życia i przenosi je do wymiaru (oderwanej od „najprywatniejszego” życia) sztuki.

Nekrolog ten jest więc przede wszystkim artefaktem - nagrobkiem (tombeau). Grób pod nim jest pusty. U Gautiera „sztuka” i „życie” są bowiem w zasadzie od siebie oddzielone nieprzekraczalną przepaścią. Poetycki nagrobek Heinego usamodzielnił się, oderwał od „najprywatniejszego żywota” niemieckiego poety. Norwidowskie „nagrobki” poetyckie zostały natomiast tak skonstruowane, że łączą „najprywatniejszy żywot” z obietnicą zmartwychwstania.

Ciekawym komentarzem do praktyki artystycznej Gautiera jest sposób, w jaki on sam charakteryzował poezję Heinego. Różnorodność natury niemiecko-żydowskiego poety została - zdaniem jego francuskiego kolegi - skutecznie wzięta w karby przez scalającą formę jego poezji, przyrównanej przez Gautiera do „najczystszej plastyczności greckiej”18:

Jamais nature ne fut composée d'éléments plus divers que celle de Henri Heine ; il était à la fois gai et triste, sceptique et croyant, tendre et cruel, sentimental et persifleur, classique et romantique, Allemand et Français, délicat et cynique, enthousiaste et plein de sang froid : tout excepté ennuyeux. À la plastique grecque la plus pure il joignait le sens moderne la plus exquis ; c'était vraiment l'Euphorion, enfant de Faust et de la belle Hélène ${ }^{19}$.

${ }^{18}$ Ciekawe, że wspomniany na początku tego tekstu prekursor symbolistów i poète maudit, Gérard de Nerval, uwydatnił tę samą dwoistość w charakterze poety (nazywa ją "mimowolną mieszanką"). Heine "ociosuje jakby bryły marmuru - sękate i bezkształtne pnie owego starego, bujnego i zawiłego lasu języka niemieckiego" („Il taille comme un bloc de marbre grec les troncs noueux et difformes de cette vieille forêt inextricable et touffue du langage allemande [...]" [H. Heine, Oeuvres complètes. Poëmes et légendes, Paris 1857, s. 110]).

19 Th. Gautier, op. cit., s. IX. 
[Nigdy nie było natury składającej się z czynników bardziej różnorodnych niż natura Henryka Heinego. Był równocześnie wesoły i smutny, sceptyczny i wierzący, sentymentalny i kpiący, klasyczny i romantyczny, niemiecki i francuski, subtelny i cyniczny, zapalczywy i pełen zimnej krwi: był wszystkim, tylko nie nudziarzem. Najczystsza plastyczność grecka szła u niego w parze z najwytworniejszą wrażliwością nowoczesną; był on naprawdę Euforionem, dzieckiem Fausta i pięknej Heleny.]

Taka poezja, której „nieskazitelna”, „marmurowa” forma niejako obejmuje i neutralizuje rozterki nowoczesnego podmiotu, nie jest chyba już romantyczna. Czy jednak wolno utożsamiać ją z dziełem sztuki odsyłającym do „pustej idealności” (Hugo Friedrich) typowej dla poezji modernistycznej? Wypada raczej uznać ją za premodernistyczną, jako że przeciwieństwo między życiem (treścią) a idealnością (formą) nie odzwierciedla w niej jeszcze rzeczywistego rozdarcia autora jako podmiotu „lirycznego”. Poezja Heinego jest - zdaniem Gautiera - pełną i wiarygodną reprezentacją jego różnorodnej i wewnętrznie spolaryzowanej natury. Mogła nią być dlatego, że forma poetycka wydaje się tu czynnikiem całkowicie niezależnym od ludzkiej subiektywności. Owa subiektywność, wcielona w osobę poety, może się swobodnie posługiwać tą formą, by wyrażać swoje uczucia, niejako je obiektywizując. Rozdarcie „duszy” nie przekłada się więc na pękniętą formę. Relacja między artefaktem a leżącą u jego podstaw subiektywnością nie wymaga głębszej refleksji „autotematycznej" ani dodatkowego uzasadnienia. Również konotacje ideologiczne treści składających się na owe poetyckie grobowce ulegają do pewnego stopnia neutralizacji. Dzieje wielkich religii ludzkości zmieniają się w obojętny z punktu widzenia światopoglądowego repertuar motywów artystycznych.

Estetyzującemu Gautierowi synkretyzm religijny przejawiający się na poziomie opisów przychodzi bardzo łatwo. Ów wychudły Chrystus, ów Łazarz, który na chwilę wyszedł z grobu w pieczarze (ale na pewno nie zmartwychwstanie), został bowiem ociosany z „pomnika greckiego boga” i może dlatego „był wciąż piękny”. Trzeba przyznać, że fragment opisu wizyty Norwida u Chopina bezpośrednio poprzedzający dialog o przeprowadzce na Place Vendôme przypomina z punktu widzenia estetycznego właśnie obraz umierającego Heinego. Różnica polega na tym, że u Norwida czynnik uwznioślający nie opiera się na sacrum chrześcijańskim. Ruchy Chopina (znamienne, że i one wiążą się z „najpowszedniejszym życiem”) kojarzą się polskiemu poecie z martwą dziś religią piękna w kulturze starożytnej Grecji:

On, w cieniu głębokiego łóżka z firankami, na poduszkach oparty i okręcony szalem, p i ę k n y był bardzo, takjak zawsze, w najpowszedniejszego życia poruszeniach mając coś skończonego, coś monumentalnie zarysowanego... coś, co albo arystokracja ateńska za religię sobie uważać mogła była w najpiękniejszejepoce cywilizacji greckiej [...]. [PW, t. 6, s. 178]

Istotowej więzi między wcielonym Bogiem a cierpiącym lub umierającym człowiekiem Norwid nigdy nie uobecnia za pośrednictwem wyłącznie estetyzujących opisów. Konstruuje w tym celu sytuacje międzyludzkie pełne dramatyzmu, w których człowiek - o ile dobrze odczytuje „realne położenie” sprzecznych racji - powinien podjąć określone działanie: „nie z krzyżem Zbawiciela za sobą - ale z krzyżem swoim za Zbawicielem idąc [...]” [PW, t. 3, s. 471]. Warto w związku z tym zestawić oba opisy umierających artystów z fragmentem 
z najsłynniejszego wiersza Norwida, Fortepianu Szopena. Tu symbole greckiej starożytności i chrześcijaństwa stopiły się w nowej jedności o charakterze mitycznym (wchodzi do niej także kultura dawnej Polski z jej dworkami szlacheckimi oraz patriotyczna tradycja Warszawy z czasów powstania styczniowego), przy czym Norwid wykorzystuje te same obrazy i motywy co wcześniej w Czarnych kwiatach. Uległy one jednak całkowitemu przeobrażeniu:

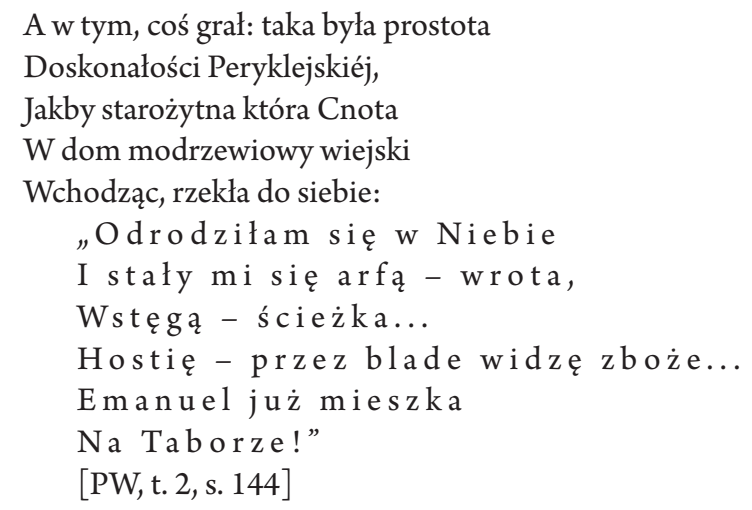

W tej reprezentacji grającego na fortepianie Chopina motywy antyczne, chrześcijańskie i staropolskie nie dają nam statycznego (wyłącznie opisowego) wizerunku artysty ani uogólniającej charakterystyki jego dzieła jak u Gautiera. Uobecniają (m.in. poprzez liczne personifikacje) pewien proces: pokazują, jak człowiek przeobraża się przez swoją własną muzykę. Wielkie religie i kultury okazują się nie tyle samowystarczalnymi tworami determinującymi zachowanie jednostek czy repertuarem artefaktów oderwanych od poszczególnych sytuacji egzystencjalnych. Istnieją one raczej jako niezastygłe, jednorazowe (dające się jednak zwielokrotnić w zasadniczo nie mniej jednorazowych aktach lektury) obiektywizacje aktów twórczych człowieka, który określa siebie wobec swojej własnej nieskończonej istoty (albo raczej niedokończonej, bo chodzi tu o ustalenie relacji między indywidualną autobiografią a Chrystusowym prawzorem autobiograficznym). Dotyczy to zarówno Chopina, jak i samego Norwida.

\section{5 .}

Wykorzystywanie konotacji religijnych w celu estetyzacji można jednak też interpretować inaczej niż w przypadku analizowanego wyżej (skądinąd zresztą świetnego) nekrologu Gautiera. Norwidowska nieskończoność (niedokończoność) wiąże się - jak widzieliśmy ściśle z chrześcijańską transcendencją oraz z ideą osobistego zbawienia (czyli nadziei zmartwychwstania). Można sobie wyobrazić również inną nieskończoność, która sferze życia codziennego przeciwstawia nie „harmonię”, do której „Pewność i Trwoga dobiegły” w królestwie niebios, lecz brak wszelkiej konkretnej treści, pustkę. Człowiek umiera i nie zostaje po nim nic (nikt). Według tej „modernistycznej” koncepcji nieskończoności żadne dzieło sztuki nie może w pełni (ani nawet częściowo) reprezentować jego prawdziwej, autobiograficznej egzystencji (różnica z wykutym z nieskazitelnego marmuru dziełem Heinego, zawierającym - zdaniem Gautiera - całokształt jego różnorodnej osobowości, rzuca się w oczy). 


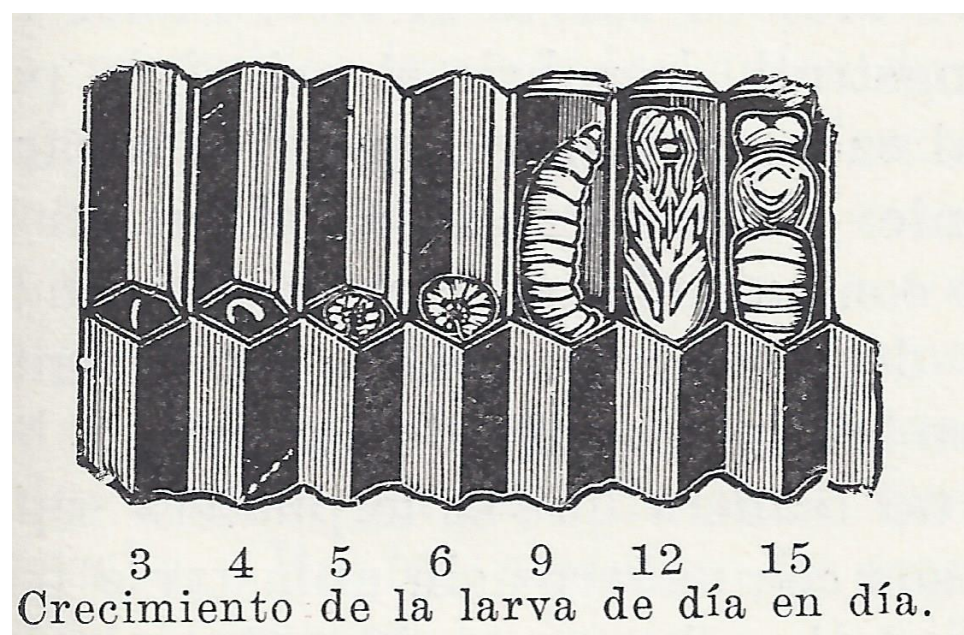

Przepaść między życiem a sztuką jest w zasadzie nieprzekraczalna. Wiersz nie reprezentuje życia człowieka, lecz depersonalizuje je. Z drugiej jednak strony: w obliczu owej nieskończonej krainy nicości, jaką jest dzieło artystyczne, status „społeczny” poety (i w ogóle człowieka) jako istoty skrępowanej konwencjami i tradycjami okazuje się nagle nieporozumieniem. Twarzą w twarz z pustką „duchową”, dającą mu nieskończoną przestrzeń dla aktów twórczych, jest on właśnie wolny j a k o p o e ta i może urzeczywistniać ową wolność, wynajdując dla wszystkich znanych sobie atrybutów i treści życiowych (należą do nich także tradycyjne symbole) nowe, jeszcze niczym nie zdeterminowane konteksty. Symbole wiary chrześcijańskiej zostały wprawdzie pozbawione przez myśl nowoczesną odniesień do życia codziennego, stając się pustymi formułami, ale właśnie dlatego mogą w modernistycznym dziele sztuki występować równolegle z treściami niesakralnymi (powszednimi, scjentystycznymi etc.). Mamy tu w istocie do czynienia z poezją „eksperymentalną”, która wykorzystuje różnorodny i wewnętrznie spolaryzowany materiał życiowy, by stwarzać świadomie sztuczne konfiguracje. Elementy (opisy przedmiotów i sytuacji) do nich wchodzące ulegają zaś przeobrażeniu nie dlatego, że znaczenia wskazujące na sacrum uobecniają je jak samodzielną istotę. „Magia” takiej poezji stwarza bowiem artefakty, które rządzą się immanentnymi prawami sztuki. Inaczej jednak niż w przypadku jednostronnie estetycznych grobowców Gautiera, owe atrybuty sakralne nie tracą swojego promieniowania „metafizycznego". Zmienia ono wszakże swoją naturę. Istotny dla wymowy utworu nie jest tu status tych atrybutów w obrębie pozawierszowej całości systemu religijnego, lecz konkretna pozycja w konfiguracji różnorodnych elementów składających się na dzieło sztuki. W tym sensie ich najgłębsza treść staje się czynnikiem formalnym.

Właśnie tak postępował Charles Baudelaire w swoich Kwiatach zła. Wykorzystywał chrześcijańską symbolikę w kontekstach, które nie tyle pozbawiały ją sakralnego znaczenia, ile przeciwstawiały innemu, równoprawnemu porządkowi sakralnemu biorącemu swój początek w złu. Dobro i zło, Chrystus i Szatan, okazują się tu nie tyle konkretyzacjami (lub personifikacjami) światoodczucia, które można by sprowadzić do pewnej ogólnej, powszechnie obowiązującej etyki, ile materializacjami (ale nie reprezentacjami) dreszczu metafizycznego przejmującego tego a nie innego człowieka hic et nunc. Pod tym względem 
punkt wyjści a Norwida nie różni się tak bardzo od Baudelaire'owskiego. U obu poetów liczy się odświeżająca dogmaty religijne, konwencje społeczne i prawa przyrody konfiguracja poszczególnych obrazów i motywów. Jej konstrukcja jest tyleż zadaniem z zakresu „matematyki twórczej”, co aktem egzystencjalnym, ale nigdy prostą reprezentacją pewnego stanu duszy. Dzięki temu doskonale znane obrazy i motywy splatają się z obrazami i motywami z zupełnie innych sfer. Piękno krzyżuje się z brzydotą, uniesienie z nudą (spleenem), atrybuty codzienności z dziełami sztuki, bluźnierstwo zaś z językiem wiary.

Owa wewnętrzna polaryzacja przestrzeni tekstu artystycznego stanowi aktualizację świadomości nowoczesnego poety, który jako c złowiek nie posiada istoty dającej się odtworzyć (albo reprezentować) w postaci d z i eła s z tu ki. W twórczości Norwida zostaje ona - jak pokazałem - przezwyciężona poprzez odniesienie do historii świętej. Rzecz jednak w tym, że w bardziej eksperymentalnych (a dlatego pozornie hermetycznych) utworach Norwida relacja między konfiguracją różnorodnych (i często sprzecznych) elementów składających się na świat przedstawiony wiersza (noweli, listu) a życiem Chrystusa lub apostołów okazuje się jednorazowym aktem ludzkiej wolności. Stąd upodobanie Norwida do zabiegów kojarzących się czytelnikowi z poetyką modernistyczną, takich jak fragmentaryczność i niespójność obrazów, prozaizacja języka, zakłócenia w rytmie etc. Pod tym względem jest on eksperymentatorem śmielszym niż kultywujący tradycyjne formy poetyckie Baudelaire.

\section{Bibliografia}

Le Faust de Goethe. Traduction revue et complète, précédée d'un essai sur Goethe par M. Henri Blaze, Paris: Dutertre, 1847.

Friedrich Hugo, Die Struktur der modernen Lyrik, Hamburg: Rowohlt, 1956.

Fieguth Rolf, Gombrowicz z niemiecka gęba i inne studia komparatystyczne, Poznań: Wydawnictwo Naukowe Uniwersytetu im. Adama Mickiewicza, 2011.

Heine Heinrich, Briefe, red. Gotthard Erler, Leipzig: Reclam, 1969.

— Oeuvres complètes. Poëmes et légendes, Paris: Michel Lévy Frères, 1857.

Mickiewicz Adam, Dzieła, Warszawa: Czytelnik, 1955.

Norwid Cyprian Kamil, Pisma wszystkie, oprac. J.W. Gomulicki, Warszawa: PIW 1971.

Gautier Théophile, Henri Heine, [w:] Reisebilder. Tableaux de voyage par Henri Heine précedée d'une étude sur H. Heine par Théophile Gautier, Paris: Michel Lévy Frères, 1856 (tekst dostępny na: http://gallica.bnf.fr/ark:/12148/bpt6k2064110/; dostęp: 22.09.2015).

Schlegel Friedrich, Werke in zwei Bänden, Berlin-Weimar: Aufbau-Verlag, 1980.

Śniedziewski Piotr, Mallarmé - Norwid: milczenie i poetycki modernizm we Francji oraz w Polsce, Poznań: Wydawnictwo Naukowe Uniwersytetu im. Adama Mickiewicza, 2008.

Zofia Trojanowicz, Elżbieta Lijewska, Kalendarz życia i twórczości Cypriana Norwida, Poznań: Wydawnictwo Poznańskie, 2007.

Żurowski Maciej, Norwid i Gautier, [w: ] idem, Między renesansem a awangarda: o literaturze europejskiej z perspektywy komparatysty, Warszawa: PWN, 2007.

— Hopkins, Mallarmé i Norwid?, [w:] idem, Między renesansem a awangardą: o literaturze europejskiej z perspektywy komparatysty, Warszawa: PWN, 2007. 